\title{
Generic Teaching Skills In English Language Teaching
}

\author{
Tagor Pangaribuan*, Kammer Tuahman Sipayung \\ University of HKBP Nommensen, Medan, Indonesia
}

*Corresponding Author: Tagor Pangaribuan, University of HKBP Nommensen, Medan, Indonesia

\begin{abstract}
Teaching english is a complex enterprise. This research is a research on teaching, developing TEFLNNs Generic Teaching Skills. The central problem of this research is competencies for a teacher to posses TEFLNNs as amodel of instruction. In particular, the research quesion is as follows: Is the experimental group with TEFLNNs Generic Teaching Skills in more significant teaching performances than the common TEFL class? To articulate the matter, the research methodology first reviews theory of generic skills, theory of instructional design, then incorporate both in teaching English in non native speaker setting. The core matter of generic skill first applies to the central notion of communicative competence in a generic skill perspective, then the TEFLNNs in teaching English profession. The finding states that epistemological praxis of generic skill in Developing TEFLNNs Generic Teaching Skills the problem solving skill, the communication and the critical thinking, makes better understanding of various difficulties in grasping the construct of communicative competence and the the complexity of TEFLNNS Teaching state of affairs. Keywords: Generic Teaching skills, Communicative Competence, TEFLNNS
\end{abstract}

\section{INTRODUCTION}

This paper attempt to present a generic instructional approach to teaching English in non native setting $\left(T E F L_{N N s}\right)$ to reach such ideal, a generic approach. In this way, this research attempts to design instructional model of teaching English in Non Native settings ( $T E F L_{N N s}$ ) Teaching today needs improvement to meet the global demand. Generic skill as a skill that works across fields and disciplines, it gets its prominent to link schools to professional works in general. While this construct is widely used, the notion varies in various praxis. In teaching English, generic skills begins to come into consideration. How meaningful this new construct is this research quest, as it is for teachers in general.

$T E F L_{N N s}$ matters problem solving in two aspects. The first is educational aspect, and the second the $T E F L_{N N S}$ itself as a field of professional service. The generic skills to master for the learner as subjects and second the way to help them learn better. In teaching English today, the first gains a more prominent, that is, English is an international language. Teaching English as an international language becomes more prominent for transnasional affairs and human contacts. So the notion of teaching English gain prominence and tend to shift to English education for global citizen. Then preparing become more prominent partifularly in preparing teachers for the matter. The central problem of this research is competencies is for a teacher to posses to deal with $T E F L_{N N s}$ asv amodel of instruction. In particular, the research quesion is as follows: Is the experimental group with $T E F L_{N N S}$ Generic Teaching Skills in more significant teaching performances than the common TEFL class?

\section{LITERATURE REVIEW}

There at least three perspectives to define generic skill, the empirical comparative, ontological, and the episgemological one. The empirical comparative Perspective defines it as key skills, core skills, transfersal skills, Quality Attributes, and the like in problem-solving skills. Thisin general takes the account of experts in the field in collaboration between world works and academic schools, and they change as to field situations. They approach the skill from its pragmatic value, among others, the five C's, Competence, Communication, Cooperation, Crativity, and Critical thinking.

Onthological Perspective originates in logic and proposition with respect to truth condition. This view take charge of an entity as generic when it gains an answer to onthological status with its logical validity, like what is a skill, a competence, a language, and the like. 
1. Generic concept

- I like potato.

- Potato was first came to Irish from South America.

- Now, potato is Irish main export.

In this sentences, the $1 \mathrm{a}, \mathrm{b}$, c potato is a casual phenomena, the second is a case but only the third (1c) as generic concept for it is a truth condition for Irish, and a generaization in economic, a singular entity, term in logic [1].

2. Generic Predication

- We are equal

- Man is born equal.

In propositional logic, the example $2 \mathrm{a}$ denotes accidentia in substance-accidentia analysis of proposition whereas $2 \mathrm{~b}$ is a logical predicate that it is self-evident and is true to the nature of humanity, a statement of truth.

In general, onthological conception of generic construt is to entail the primitive questions in philosophical science to generate the constituents of a scientific object, as common in a goal-meansends analysis in philosophy. It defines how an entity from its essence, its analysis by intelligence and its significance in a scientific enterprise to state if it is a constituent or a subconstituent in its study.

Epistemological perspective [2] is first developed by Jone o make a more comprehensive view for education. Epistemology is the study how a knowledge is a theory, as done in academic activity. The epistemological appratus includes the way a scientist works in education, doing a subject, sharing and communciating to its learners, and making a common shared knowledge, again to reach a goal-meansends analysis in philosophy but further in field works. He identifies three generic constituents, problem-solving, communication, and critical thinking.

Problem-solving is discerning a reality in the state of affairs. In common phlosophical quest, it is a skill to do a goal-means-ends analysis to settle a state or a phenomena, like from the unkwon to th known state of affairs. A scientist in common does this as a study on onthological, epistemological and axeological perspective to generate a knowledge, and a common academic task in learning. For better learning, teacher makes them more pragmatic. It is directed to a problematic situation. [13] defines this in five steps, as follows.

\section{Problem-Solving skills}

Step-1: The individual confronts a problematic situation that causes confusion or puzzlement she must resolve.

Step-2: The individual exactly define with the problom is

Step-3: Clarification of the problem consists of a careful examination or analysis of the factors contributing to the problem.

Step-4: Develop hypothesis if..then statements that offer possible solution to the difficulty, and solution alternative.

Step-5: The individual select ONE hypothesis and implement; if it works, continue. If it does not, choose from the alternatives.

Communication deals with how a learner or an actor conveys the generic notion in a give community to which he is attached to. It matters with acceptability, deal and interpersonal relation to maintain the community climate on its right track. It matters with sharing, cooperating, discussing and making the generic matter shared altogether. Critical thinking deals with how a person makes a grasp of a generic notion in the author's perspective in one sense, and grasp its essence in the other for wider and better value.

\subsection{Generic Teaching Skills in $\mathrm{TEFL}_{\mathrm{NNs}}$}

Teaching is a teacher's enterprise. He is doing it in classroom. In a simple synoptic, a teacher is greeting students, explaining the matter, ask learners participants and o the homework. This has been the teaching trade, and a tradition. But, when a search of teaching is done, it is an interaction between 
a teacher and his community, the classroom subjects, the pupil. There are thick layers of rational how a teacher is doing what he is doing. Instruction matters such, as teaching enterprise. It designates construct complex from various perspectives. The analogy takes place in teaching English, including how a teacher is doing it in non native settings $\left(T E F L_{N N S}\right)$.

The non native setting of teaching English is an enterprise. The activity is done by a non native speaker of the English but communicate in it to non native learners in non native setting. From place to place, almost in the world settings this takes places, in many nations and people. Then it is a unique enterprise, it is doing a foreign thing in a foreign setting with foreign language leaerners.

\subsection{TEFL ${ }_{\mathrm{NNs}}$}

$T E F L_{N N S}$ is a construct. The challenge to teachers in $T E F L_{N N s}$ in general is Generating a Coherent Vew of TEFL ${ }_{N N s .}$. In general, it is an amalgam of philosophies and philosophies on language, language teaching and learning, communication, and all its descendeants, with communicative competence as learning outcomes, and educational enterprise in general, [3]. So, it is a critical enterprise to generate meaningfulness in instructional design of $T E F L_{N N s}$.

As an educational enterprise, $T E F L_{N N S}$ deals with instruction. Instruction functions to help better learning and it keeps its principle, [4].

4. First Principle of Instruction: Instructional Basics

- Select an instructional context

- Develop a growth schema

- Select problem-solving goals for the students

- Develop practice materials

- Develop teaching learning strategies

- Design assessment tools

- Develop the sequence of instructions in instructional events and realize them in lesson plans.

In TEFL, thisfirst principle is acquired in learning by doing, three phases, the lesson planning, the presentation, and class participation conference, or critical participation. Within these three phases, studens strive to acquire the teaching skills as learning outcomes.Given that a generic skill is made up of simpler skills and knowledge, we can use the principles for teaching each of those components, [5].

Generic skills comprises the first principles of instruction in lesson plan. Further improvement is doing with generic skills. A generic skill is a skill which: it can be applied across a variety of subject domains, and it takes longer to acquire than domain-dependent (subject-area) skills. [4] states that there are three constituents of generic skills in teaching related to epistemologcal processing in classroom, problem-solving, communication and critical thinking. [6] argues that with the problemsolving steps, students as participants in their enterprise apply the steps to do lesson planning.

\subsection{Communicative Competence in TEFLNNs}

In TEF $L_{N N s,}$ communicative competence is the target learning outcomes. By its hisorical concept [7], it grew from hetorical and grammatical skills in Plato's Organon, then becomes language skills in the ASTP Programs, then with literay competence, and now with Dell Hymes' communicative competence, the language comprises all as language tacit knowledge for communication of its user.

To conceive the notion of communicative competence, students of $T E F L_{N N S}$ learns various methods from their texts, among others, communicative approach, direct method, total-physical response and the like. Methods in TEFL are generated from its underlying philosophy. [7] notes that methods in English language teaching in the beginning started from Plato's era to the present state of affairs. In the beginning, language study constitutes soungs and meanings and grammar functions to link the speaker's meaning and idea to the physical sounds, and human being is born with innate capacity to master the language. Since then the language studies developed and the latest stated that language is acquired in a creative-construction hypothesis rooted in Chomsky's universal grammar, [8]. Hymes to certain extent acknowledge the notion of Chomsky's competence as tacit knowledge linguistic cmpetence but put foreard the linguistic performance accommodating Saussure's la parole that meaning plays a central function in language communication, [9]. 
Communicative competence then is the tacit knowledge of native speaker doing a communicative acts. Originated in [12] How to Do Things with Words, Hymes develop and propose SPEAKING as the construct of the tacit knowledge, and Searle develops as speech acts, and all these notion is almost universally TEFL ${ }_{N N S}$ Hymes, further says that teaching requires contextuality. For the construct of communcative competence, he puts emphasis on the importance of human ability to create context through language to build communcative brilliance, [10] to reinvent what we ask ourselves, responsiveness, critical awareness, human relevance. His SPEAKING model attach for this. In teaching English as a foreign language this becomes crucially important for global communication. Its teaching praxis is a novel enterprise. Future language teachers needs knowledge substantive knowledge to support their teaching skills supporting their knowledge of TEFL methods. They need model how to accommodate those they have learned in lesson planning.

For Hymes, SPEAKING communicative competence is the tacit knowledge model for communication. It constitutes as a whole the notion of SPEAKING that within any communicative act therr are inherent as a whole Setting, Participants, Ends, Acts. Keys, Instrumentalities, Norm, Genre. This parameter helps understand the notion of communicative event and context of communication.

There are infinite events and contexts in comunications, with respect to its users and uses such as by learners, by professions, age, by people, by education, by culture and the like. Dispite these mass data, teachers by garsping SPEAKING constituents make a generic knowledge of the matter.they learn rule of speaking $\mathrm{n}$ general, how ut varies across its variables in the parameter of SPEAKING as context. Teachers tehn can generate models of speeech acts for a given communicative event with the SPEAKING as its parameter.

\subsection{Generic Skills in Communicative Competence}

The notion communicative competence is basically generic to do problem solving in communication and to get things done through negotiation, deal, enterprise and the like. By context and and use, it universally applies to human. In today's state of the arts, they are sometimes named as communication skills to make it closer to world affairs such as business, conference, and the like. It is a generic skills and in its praxis, named as communication. In TEFL perspective, it can articulate in the process of language formation, language learning and language praxis, and varies in various ESP domain. As a generic skill, it is a skill which: it can be applied across a variety of subject domains, and it takes longer to acquire than domain-dependent (subject-area) skills. For classroom teaching practice, two main aspects are applied, the discourse and the speech acts.

In speech act communication, grice' maxim works. [11] makes your contribution as needed. Grice launches cooperative principles as communicative code in communicating. It desgnates maxims of quality, quantity, manner and relevance. In this way, communicative cometence gains richer notion for elegance, and complexity as well.In classroom praxis, communicative competence is identified as communicative events, such as events in Hotel receptionist, Bank teller, Doing Interview, Tour Guide, Discourse of story telling. Each of these is observed as a communicative event using SPEAKING constituents.

5. Context : A customer from Taipei is booking, online, at Danau Toba International Hotel, Medan Indonesia

$\begin{array}{ll}\text { Customer } & : \text { Excuse me, is this Danotoba international? } \\ \text { Receptionist } & : \text { Yes, please. Can I help you? } \\ \text { Customer } & : \text { I d like to book a room for two days, if available. } \\ \text { Receptionist } & : \text { For your choices, we have standard classes of president, executive, } \\ & \text { suite, and common class. } \\ \text { Customer } & : \text { How are they? } \\ \text { Receptionist } & : \text { Well, our hotel offers standard, president US } \$ 100, \text { executive } \$ 75, \\ & \text { suite } \$ 50, \text { and common class } \$ 25, \text { including tax servce sir,. } \\ \text { Customer } & : \text { Fine, I ll book for uesday and Wednesday. My name is Jhonny Lee, } \\ & \text { tourist, Thank you. } \\ \text { Receptionist } & : \text { Alright, we note you; Welcome }\end{array}$


Teacher in $T E F L_{N N S}$ conceives the receptionist-custemer event as a single communicative event that can be observed as speech acts and speech discourse in communication. This is done to analyze to what extent the negotiation in communication successful and how rules of SPEAKING work.

Viewing Communicative Competence as generic skill and its perspective constitutes three constituents, problem-solving, communication, critical thinking. In the first place, the learner understand the Communicative Competence as problem solving in a goal-means-ends analysis to settle commnication affairs, the SPEAKING construct. Secondly, the learner communicates his/her tacit knowledge of the construct in classroom community. Finally, he makes a bird-eye-view of the state of affairs.

\subsection{TEFL NNsIn Generic Perspective: Generic Teaching Skills}

In teaching matter, $T E F L_{N N S}$ articulate generic teaching in general and follow the first principle of instruction, with lesson plan as the design. A teacher is doing the what and the how to do what as learning outcomes and the lesson plan how to help learners learn better.In others, methods in language teaaching offers various instructional approachand strategies how language teaching in general is transformed into classroom tasks, and how the learners do the learning and acquisition.

Students learn to undestand TEFL Methods in various subjects such as the nature of competence and acquisition in psycolinguistics, the mater of language use in sociolinguistics, and the values of communicative codes in pragmatics. In line with, they learn methods in the TEFL subjects, TEFL approaches and Lesson Planning. Various methods disccuseed across the subjects are communicative approach, ttal physical response, CLL, and the like, [12].

The first principle of insruction $\langle 6\rangle$ is the whole teaching states. Learners conceive the notion as the whole state of affairs as a teaching paradigm. When it matters with classroom teaching tasks, they are stages in action, and in sequence the framework can be dones as follws,

6. Stages of instruction

- Lesson Planning

- Presentation

- Participation and Reflection

In all teaching process, the doing of teaching is observed as epistemological praxis asProblem solving, Communciation, and Critical Thinking, [6]. TEFL ${ }_{N N s}$ is a construct of instructional design. The construct is a hybrid of instructional design as generic skillsand generic notions from TEFL methods, and hence, they can be mind-map as follows.To conclude the state of the arts, the instructonal model to practice in $T E F L_{N N S}$ is as follows.

7. Generic Teaching Skill construct

\begin{tabular}{|l|l|l|l|}
\hline \multicolumn{4}{|c|}{ TEFL $_{N N s}$ Construct Generic Skills } \\
\hline Teaching Praxis & Communicaton & Poblem Solving & Critical thinking \\
\hline Lesson Plan & & & \\
\hline Presentation & & & \\
\hline Participation & & & \\
\hline
\end{tabular}

In teaching performance observation, this construct is articulated in a five scale category of classroom epistemological praxis, as follows.

8. Epistemological Praxis

\begin{tabular}{|l|l|l|l|l|l|}
\hline $\begin{array}{l}\text { Generic } \\
\text { Aspects }\end{array}$ & \begin{tabular}{l}
$\mathbf{1 - 2 0}$ \\
\cline { 2 - 6 } \\
concept the
\end{tabular} & $\begin{array}{l}\text { Grasp Reach only } \\
\text { problem not } \\
\text { solving to certain } \\
\text { extent }\end{array}$ & $\begin{array}{l}\text { Grasp Reach } \\
\text { problem } \\
\text { solving to } \\
\text { certain extent }\end{array}$ & $\begin{array}{l}\text { 61-80 } \\
\text { problem solving } \\
\text { to certain extent at } \\
\text { minimum level }\end{array}$ & $\begin{array}{l}\text { Grasp } \\
\text { problem } \begin{array}{l}\text { Reach } \\
\text { solving } \\
\text { satisfactory } \\
\text { level }\end{array}\end{array}$ \\
\hline Lesson Plan & & & & & \\
\hline Performance & & & & & \\
\hline $\begin{array}{l}\text { Conference } \\
\text { and reflection } \\
\text { participation }\end{array}$ & & & & & \\
\hline
\end{tabular}


9. Construct observation of Generic Skills at epistemological praxis can be observed in the following table

\begin{tabular}{|c|c|c|c|c|c|}
\hline \multirow{2}{*}{$\begin{array}{l}\text { Generic } \\
\text { epistemological } \\
\text { praxis }\end{array}$} & $1-20$ & $21-40$ & $41-60$ & 61-80 & $81-100$ \\
\hline & $\begin{array}{l}\text { Fulfill the } \\
\text { concept }\end{array}$ & $\begin{array}{l}\text { Grasp Reach only } \\
\text { problem not } \\
\text { solving to certain } \\
\text { extent }\end{array}$ & $\begin{array}{l}\text { Grasp Reach } \\
\text { problem } \\
\text { solving to } \\
\text { certain extent }\end{array}$ & $\begin{array}{l}\text { Grasp Reach } \\
\text { problem solving } \\
\text { to certain extent } \\
\text { at minimum level }\end{array}$ & $\begin{array}{l}\text { Grasp } \\
\text { problem soach } \\
\text { to solving } \\
\text { level }\end{array}$ \\
\hline \multicolumn{6}{|l|}{$\begin{array}{l}\begin{array}{l}\text { Problem } \\
\text { Solving }\end{array} \\
\end{array}$} \\
\hline \multicolumn{6}{|l|}{ Communciation } \\
\hline $\begin{array}{l}\text { Critical } \\
\text { Thinking }\end{array}$ & & & & & \\
\hline
\end{tabular}

\subsection{Generic Teaching Skill}

Generic teaching skill is a construct in the sense that it is a cross-interfaces of the discipline of generic skill, TEFL, and instructional design altogther. The mind of the generic teaching skill for classroom epistemological praxis can be mapped as follows.

\begin{tabular}{|c|c|c|c|c|c|c|}
\hline \multirow{3}{*}{$\begin{array}{l}\text { Generic } \\
\text { Teaching Skill }\end{array}$} & & \multicolumn{5}{|c|}{ Indicator of Generic Aspect Performances } \\
\hline & & \multicolumn{2}{|c|}{\begin{tabular}{|l|l|}
$1-20$ & $21-40$ \\
\end{tabular}} & $41-60$ & 61-80 & 81-100 \\
\hline & $\begin{array}{l}\text { Generic } \\
\text { Aspects }\end{array}$ & $\begin{array}{l}\text { Fulfill } \\
\text { the } \\
\text { concept }\end{array}$ & $\begin{array}{l}\text { Grasp Reach } \\
\text { only problem } \\
\text { not solving to } \\
\text { certain extent }\end{array}$ & $\begin{array}{l}\text { Grasp Reach } \\
\text { problem } \\
\text { solving to } \\
\text { certain extent }\end{array}$ & $\begin{array}{l}\text { Grasp Reach } \\
\text { problem } \\
\text { solving to } \\
\text { certain extent } \\
\text { at minimum } \\
\text { level }\end{array}$ & $\begin{array}{l}\text { Grasp } \\
\text { Reach } \\
\text { problem } \\
\text { solving to } \\
\text { satisfactory } \\
\text { level }\end{array}$ \\
\hline \multirow{3}{*}{$\begin{array}{l}\text { Problem } \\
\text { Solving }\end{array}$} & Lesson Plan & & & & & \\
\hline & Performance & & & & & \\
\hline & $\begin{array}{l}\text { Conference } \\
\text { and reflecion } \\
\text { participation }\end{array}$ & & & & & \\
\hline \multirow[t]{3}{*}{ Communication } & Lesson Plan & & & & & \\
\hline & Performance & & & & & \\
\hline & $\begin{array}{l}\text { Conference } \\
\text { and reflecion } \\
\text { participation }\end{array}$ & & & & & \\
\hline \multirow{3}{*}{$\begin{array}{l}\text { Critical } \\
\text { Thinking }\end{array}$} & Lesson Plan & & & & & \\
\hline & Performance & & & & & \\
\hline & $\begin{array}{l}\text { Conference } \\
\text { and } \\
\text { reflective } \\
\text { participation }\end{array}$ & & & & & \\
\hline
\end{tabular}

\section{Methodology}

The Research is carried out in one semester in TEFL classes. in undergraduate, English department, HKBP Nommensen University. One class is with generic skill praxis, and the other as control. For the experimental treatment, the learners are equiped with models of generic materials, teaching demonstrations and then students make lesson plan project. The results are video-taped, then presented $\mathrm{n}$ classroom with class conference and participation.

For inception strategies, the class watches traditional on going teaching in TEFL classes in various grades. This then leads to discussion on what teaching is as it is and the challenge for suach states. Then it follows various models of communicative competence in actions, among he models, the instructors, students and the like.

Instructor select some communicatve events. The students generate the tacit knowledge from the communicative events, consult instructors and shared in class, and do the task. Students chose the topics in their preferences, then develop models of speech acts. Then, they develop lesson plans, practice in their group, and the results are vidio-taped. The communicative events chosen by students takes five communicative events, as follows. 


\section{Comunicative events $\rightarrow$ Speech acts $\rightarrow$ lesson Plan}

- Hotel receptionist

- Bank teller

- Doing Interview

- Tour Guide

- Discourse

Students under guidance develop the concepts as for the mastery of the speech acts first then doing the lesson plan, the teaching, and the presentation. Concference and reflections are done in classroom, after the student develops their initial model of presentation. Some high lihts are given either in classroom action cycle or simple steps, but classroom conference and reflections help the students improve their project.

\section{Praxis High-light}

- Students record teaching processes from cycle one to cycle four.

- The lecturer lead a conference for each teaching action for performance rehabilitation, improvement and suggestion.

- Students recycles the teaching in their groups

- Lecturer give inputs among the ELT methods and techniques and modeling the generic competence for the define characters.

- The students recycle the teaching with the ELT methods as inputs, and record the teaching.

- Tuning up with conference and reflections.

\section{FINDINGS}

The process-product of of the tasks carried out in the research is presented in scale of classroom observation as follows.

Table4: TEFL Group A Experimental Group

\begin{tabular}{|l|l|l|l|l|l|l|l|l|l|l|l|}
\hline \multirow{2}{*}{ Subjects } & \multirow{2}{*}{ Gender } & \multicolumn{3}{|c|}{ Problem-solving } & \multicolumn{3}{c|}{ Communication } & \multicolumn{3}{c|}{ Critical Thinking } & Total \\
\cline { 3 - 13 } & & LP & $\mathbf{P}$ & $\mathbf{C P}$ & $\mathbf{L P}$ & $\mathbf{P}$ & $\mathbf{C P}$ & $\mathbf{L P}$ & $\mathbf{P}$ & $\mathbf{C P}$ & \\
\hline 1 & 2 & 50 & 44 & 78 & 65 & 75 & 55 & 66 & 45 & 60 & 538 \\
\hline 2 & 1 & 55 & 48 & 55 & 45 & 50 & 25 & 45 & 60 & 39 & 422 \\
\hline 3 & 1 & 24 & 33 & 45 & 30 & 32 & 58 & 40 & 28 & 40 & 330 \\
\hline 4 & 1 & 60 & 50 & 59 & 44 & 59 & 24 & 37 & 26 & 40 & 399 \\
\hline 5 & 2 & 76 & 59 & 77 & 75 & 79 & 55 & 77 & 50 & 69 & 617 \\
\hline 6 & 1 & 57 & 55 & 53 & 50 & 59 & 33 & 35 & 40 & 35 & 417 \\
\hline 7 & 1 & 55 & 45 & 52 & 50 & 54 & 35 & 45 & 35 & 40 & 411 \\
\hline 8 & 1 & 57 & 47 & 33 & 33 & 30 & 36 & 40 & 39 & 40 & 355 \\
\hline 9 & 1 & 77 & 77 & 70 & 70 & 79 & 53 & 79 & 66 & 57 & 628 \\
\hline 10 & 1 & 90 & 79 & 73 & 88 & 95 & 54 & 78 & 77 & 56 & 690 \\
\hline 11 & 1 & 79 & 80 & 55 & 70 & 70 & 55 & 77 & 76 & 55 & 617 \\
\hline 12 & 1 & 78 & 70 & 54 & 50 & 50 & 25 & 59 & 48 & 25 & 459 \\
\hline 13 & 2 & 55 & 50 & 79 & 70 & 59 & 29 & 56 & 50 & 40 & 488 \\
\hline 14 & 1 & 50 & 59 & 57 & 55 & 55 & 30 & 58 & 23 & 36 & 423 \\
\hline 15 & 1 & 55 & 55 & 35 & 25 & 45 & 55 & 40 & 24 & 35 & 369 \\
\hline 16 & 1 & 58 & 45 & 40 & 30 & 38 & 38 & 39 & 24 & 40 & 352 \\
\hline 17 & 1 & 56 & 47 & 37 & 30 & 35 & 39 & 36 & 25 & 37 & 342 \\
\hline 18 & 1 & 55 & 59 & 35 & 33 & 39 & 40 & 38 & 35 & 36 & 370 \\
\hline 19 & 2 & 60 & 50 & 36 & 35 & 35 & 40 & 39 & 33 & 35 & 363 \\
\hline 20 & 1 & 45 & 59 & 58 & 53 & 55 & 42 & 59 & 55 & 60 & 486 \\
\hline 21 & 1 & 50 & 29 & 40 & 37 & 38 & 25 & 40 & 40 & 40 & 339 \\
\hline 22 & 1 & 77 & 78 & 55 & 72 & 77 & 60 & 79 & 55 & 54 & 607 \\
\hline 23 & 1 & 55 & 55 & 60 & 58 & 55 & 56 & 55 & 56 & 55 & 505 \\
\hline 24 & 2 & 30 & 40 & 50 & 28 & 38 & 38 & 34 & 24 & 40 & 322 \\
\hline 35 & 1 & 50 & 55 & 59 & 50 & 55 & 60 & 45 & 55 & 55 & 484 \\
\hline
\end{tabular}




\begin{tabular}{|l|l|l|l|l|l|l|l|l|l|l|l|}
\hline 26 & 1 & 59 & 58 & 55 & 48 & 55 & 59 & 54 & 60 & 50 & 498 \\
\hline 27 & 1 & 55 & 60 & 45 & 45 & 57 & 55 & 55 & 58 & 59 & 489 \\
\hline 28 & 1 & 45 & 28 & 47 & 31 & 38 & 37 & 29 & 23 & 33 & 311 \\
\hline 29 & 2 & 47 & 50 & 80 & 63 & 78 & 77 & 50 & 78 & 54 & 577 \\
\hline 30 & 1 & 59 & 59 & 78 & 48 & 58 & 56 & 59 & 53 & 49 & 519 \\
\hline 31 & 1 & 78 & 55 & 65 & 63 & 77 & 57 & 55 & 54 & 48 & 552 \\
\hline 32 & 1 & 56 & 45 & 50 & 53 & 58 & 58 & 45 & 56 & 57 & 478 \\
\hline 33 & 2 & 38 & 47 & 59 & 52 & 55 & 57 & 47 & 54 & 56 & 465 \\
\hline 34 & 1 & 55 & 59 & 55 & 45 & 51 & 55 & 59 & 56 & 55 & 490 \\
\hline 35 & 1 & 59 & 35 & 45 & 23 & 35 & 38 & 40 & 40 & 17 & 332 \\
\hline \multicolumn{8}{|c|}{ Total } \\
\hline
\end{tabular}

Note $: L P=$ Lesson Plan, $P=$ Presentation, $C P=$ Critical Participation, $1=$ female, $2=$ male

Table4: Group B control Group

\begin{tabular}{|c|c|c|c|c|c|c|c|c|c|c|c|}
\hline \multirow[b]{2}{*}{ Subjects } & \multirow[t]{2}{*}{ Gender } & \multicolumn{3}{|c|}{ Problem-solving } & \multicolumn{3}{|c|}{ Communication } & \multicolumn{3}{|c|}{ Critical Thinking } & \multirow[b]{2}{*}{ Total } \\
\hline & & LP & $\mathbf{P}$ & $\mathbf{C P}$ & LP & $\mathbf{P}$ & CP & LP & $\mathbf{P}$ & CP & \\
\hline 1 & 1 & 80 & 59 & 43 & 80 & 67 & 58 & 70 & 55 & 57 & 569 \\
\hline 2 & 2 & 60 & 60 & 45 & 60 & 55 & 57 & 55 & 55 & 39 & 486 \\
\hline 3 & 1 & 80 & 76 & 70 & 60 & 24 & 18 & 35 & 35 & 19 & 417 \\
\hline 4 & 1 & 40 & 25 & 32 & 40 & 25 & 19 & 19 & 20 & 18 & 238 \\
\hline 5 & 1 & 40 & 35 & 36 & 35 & 28 & 40 & 38 & 27 & 27 & 306 \\
\hline 6 & 1 & 60 & 55 & 55 & 55 & 55 & 32 & 39 & 31 & 35 & 417 \\
\hline 7 & 1 & 59 & 54 & 56 & 45 & 56 & 29 & 60 & 34 & 35 & 428 \\
\hline 8 & 2 & 60 & 53 & 29 & 40 & 23 & 36 & 37 & 35 & 27 & 340 \\
\hline$\overline{9}$ & 1 & 40 & 45 & 57 & 79 & 80 & 69 & 40 & 55 & 20 & 485 \\
\hline 10 & 1 & 58 & 79 & 72 & 91 & 87 & 71 & 77 & 80 & 55 & 670 \\
\hline 11 & 1 & 59 & 80 & 60 & 78 & 77 & 30 & 55 & 35 & 40 & 514 \\
\hline 12 & 1 & 79 & 45 & 56 & 60 & 55 & 46 & 56 & 44 & 38 & 479 \\
\hline 13 & 2 & 59 & 55 & 57 & 77 & 56 & 45 & 57 & 48 & 35 & 489 \\
\hline 14 & 1 & 60 & 56 & 58 & 55 & 58 & 37 & 60 & 29 & 36 & 449 \\
\hline 15 & 1 & 59 & 57 & 24 & 33 & 25 & 36 & 35 & 31 & 39 & 339 \\
\hline 16 & 1 & 58 & 34 & 25 & 33 & 26 & 34 & 36 & 33 & 40 & 319 \\
\hline 17 & 1 & 58 & 57 & 33 & 36 & 27 & 33 & 38 & 34 & 25 & 341 \\
\hline 18 & 1 & 60 & 58 & 35 & 40 & 28 & 32 & 40 & 34 & 35 & 362 \\
\hline 19 & 1 & 60 & 44 & 35 & 40 & 38 & 25 & 39 & 35 & 38 & 354 \\
\hline 20 & 1 & 60 & 45 & 54 & 55 & 57 & 44 & 57 & 60 & 60 & 492 \\
\hline 21 & 2 & 57 & 36 & 27 & 37 & 40 & 31 & 36 & 29 & 38 & 331 \\
\hline 22 & 1 & 80 & 70 & 47 & 79 & 62 & 55 & 77 & 51 & 52 & 573 \\
\hline 23 & 1 & 60 & 55 & 50 & 58 & 48 & 54 & 56 & 56 & 53 & 490 \\
\hline 24 & 1 & 40 & 35 & 30 & 40 & 35 & 35 & 38 & 35 & 39 & 327 \\
\hline 35 & 1 & 58 & 58 & 54 & 60 & 55 & 57 & 57 & 55 & 48 & 502 \\
\hline 26 & 1 & 59 & 43 & 55 & 56 & 56 & 56 & 48 & 56 & 59 & 488 \\
\hline 27 & 2 & 60 & 45 & 48 & 57 & 45 & 60 & 55 & 48 & 56 & 474 \\
\hline 28 & 1 & 56 & 23 & 49 & 38 & 38 & 29 & 40 & 29 & 37 & 339 \\
\hline 29 & 1 & 80 & 47 & 31 & 77 & 78 & 22 & 36 & 26 & 36 & 433 \\
\hline 30 & 1 & 79 & 48 & 80 & 55 & 56 & 44 & 49 & 54 & 54 & 519 \\
\hline 31 & 2 & 80 & 49 & 40 & 79 & 80 & 35 & 38 & 38 & 31 & 470 \\
\hline 32 & 1 & 60 & 60 & 57 & 58 & 60 & 47 & 60 & 60 & 41 & 503 \\
\hline 33 & 1 & 78 & 55 & 57 & 58 & 56 & 46 & 53 & 54 & 54 & 511 \\
\hline 34 & 1 & 60 & 55 & 57 & 53 & 54 & 45 & 53 & 55 & 57 & 489 \\
\hline & & & & & otal & & & & & & 14943 \\
\hline
\end{tabular}

Note $: L P=$ Lesson Plan, $P=$ Presentation, $C P=$ Critical Participation, $1=$ female, $2=$ male

The data analysis in the appendix "corrected model" shown the significant effect to the whole indevenden variable gender, experiment and control along with interaction between gender and group togather with dependen variable. When the significan value $<0.05$, means has a significant effect. In the corrected model shown that problem solving on critical participation has significant influence $(0.009<0.05)$. in other words, whole indevenden variables have s significant effect on problem solving - critical participation. In addition to that, gender has no significant effect on each generic skill. Finally the data analysis proves that the experimental group is significant. 


\section{DISCUSSION}

\subsection{Commnicative Competence}

As a matter of fact, defining communicative competence is nasty matter. Students reading the concept in references, discussing, and sharing not always makes a clear point. Discussing hetorical skill, language skills, listening, speaking, reading comprehension and writing are common abstract generic concepts for students. How such constructs mean and articulate in classroom sometimes make a tough challenge for students for a comprehensive norion and a clear grasp.

Learning by doing it, and practicing communicative events and summing the speech act competence is a learning by doing praxis that enhance understanding. Doing the speech act communicative processing and demonstrating it helps students see the matter. It help grasp the notion what communicative competence in a given setting is. Besides, learning from other communicative ompetence models help observe how it may differs and perform better. Sharing and reflecting with demonstration performance enhance understanding to the notion of the competence.

\subsection{Generic View of Communicative Competence}

The process in learning by doing with generic skills praxis help the problem solving of this notion in a quite comprehensive goal-means-ends analysis.Learners learn to grasp a communicative event, doing a SPEAKING constituents, demonstrating various models, and observing their models in their own terms make them get internalized to the essence of the tacit knowledge how the language works in roles participants in their contexts. They get two birds with one stone. First, they learn to make their mown, then they present the model. Secondly they conceive the process as speech act ccompetence. In one way student creatively makes speech acts and some of its analogous variants, and share them with other groups in class conference.

\subsection{TEFLNNs Generic Teaching Skills}

Student practice teaching praxis in complexity of its affairs. In the initial stages, they get enhance to teach with thier free will in their groups. They make their own speech acts, they model it, and create its analogies. Through classroom relections, they learn to refine the speech acts to be genuine, polite and nice. Videotaping speech acts make them see who they are in English communicating. This help them see as non native reaching their internaional English in learning by doing.

Meanwhile, communicating the teaching matters and affairs motivate new challenges for both leacturer and students. With the reflection process, students throug overviewing the teaching and the videotape to certain extent offers a self-reflection how-I-am-doing in in my view and others. Communiating such teaching matters become a new affair and the direction for empathy is necessary that dispite some errors and odds, every candidate learns to respect for a continous improvement.

Participants along the experiment deals with teaching complexity. In one way, teaching is a strive for a teacher. Doing it with a garsp of learning-by-doing helps understand that learning, acquisition an gaining communicative competence at generic level is not simple at all, but a process to an end. Lesson plannng and presentation, and recyling the processes help some improvement altheway.

\section{CONClusion}

Generic perspective in teaching is a new enterprise. This reach on in TEFL ${ }_{N N S}$ Generic Teaching Skills is just a begining. The research shows some enlightenment that learning by doing with generic skill perspective offers some significant classroom praxis of defining communicative competence for classroom, and how the matter of problem solving, teaching communication, and critical thinking become an inherent path of the process.With generic perspecgive, research offer more challenging insights in epistemological praxis of TEFL, its problem-solving, teaching communication and critical overview. Hence, doing similar research is worth to enrinch TEFL profession and new urther insight.

\section{ACKNOWLEDGEMENT}

The great thanks is delivered to KEMENRISTEK DIKTI of Indonesia who funded this research. Without helping of KEMENRISTEK DIKTI, this reseach can not done perfectly and the great honor is delivered to the tim of this reseach who has already given their contribution to conduct this research. 


\section{REFERENCES}

[1] Benthem.J.V \& Meulen .T.A, Handbook of Logic and Language, Elsevier, The MIT Press, Cambridge University Press, 1997.

[2] Miller, John P \& Seller, Wayne Curriculum Perspective and Practices, New York: Longman, 1985.

[3] Nunnan, David, Second Language Learning and Teaching, USA, Heinle \& Heinle Publishers, 1999.

[4] Charless M Reigeluth, Instructional-design Theories and Models, Vol I, Rouletge, Taylor and Francis Publisher, 1982.

[5] Charless M Reigeluth, Instructional-design Theories and Models, Vol III, Rouletge, Taylor and Francis Publisher, 1999.

[6] Anna Louise Jones, Redisciplining generic skills: An examination of the relationship between the disciplinary context and generic skills in Hiher Education, Center for Study of Higher Education, Faculty of Education, University of Melbourne, 2006.

[7] Pangaribuan.T, TEFL-1 Generic Teaching Skills, Graduate School, HKBP Nommensen University, 2015(Research Grant, Kepmenristek, RI), 2016.

[8] Chomsky, New Horizon in the study of language and Mind, Cambridge University Press, 2000.

[9] Hymes, Dell, Foundation in Sociolinguistics: An Ethnographic Approach. Philadelphia: University of Pensylvania Press, 1974.

[10] Hymes, Dell, in Nancy H Hornberger, Dell Hymes, His Scholarship and Legacy in Anthrophology and Education, GSE Publication, Graduate School of Eucation, 2011.

[11] Grice, H.P. Logic and Conversation, Syntax and Semantics, Vol.III. Speech Acts, (Editor: Peter Cole \& Jerry L. Mogan), New York, 1975.

[12] Austin, J.L. How to do Things with Words. London: Oxford University Press, 1962

[13] John Dewey, in Miller, John P \& Seller, Wayne Curriculum Perspective and Practices, New York: Longman, 1985.

\section{AUTHOR's BIOGRAPHY}

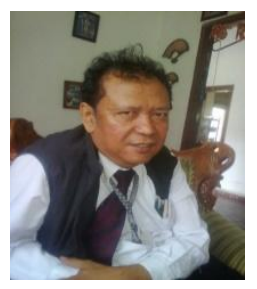

Tagor Pangaribuan holds a $\mathrm{PhD}$ in English Education (University of Negeri Malang-Indonesia). His research focused on teaching English as a foreign language from the beginner level. He develops and innovates some model and instrument of teaching. He wrote many kinds of TEFL books and teaches philosophy of TEFL and ESP at University of HKBP Nommensen.

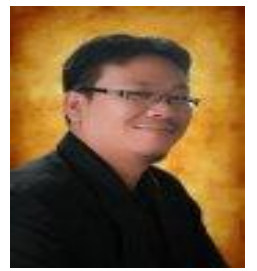

Kammer Tuahman Sipayung holds an MPd in English Education (University of HKBP Nommensen) and he is a student of $\mathrm{PhD}$ in Linguistic (Universitas Sumatera Utara). His research interest centered on the applied linguistic particularly on translation, discourse analysis and TEFL. He has already published several articles on national and international seminar and national and international journal. The government of Indonesia believe him some granted reseach to do.

Citation: Tagor Pangaribuan, Kammer Tuahman Sipayung. "Thomas Hardy: A Better Understanding of his Claimed Pessimism, its Causes and Influence" International Journal on Studies in English Language and Literature (IJSELL), vol 6, no. 7, 2018, pp. 6-15. doi:http://dx.doi.org/10.20431/2347-3134.0607002.

Copyright: ( $\odot 2018$ Authors. This is an open-access article distributed under the terms of the Creative Commons Attribution License, which permits unrestricted use, distribution, and reproduction in any medium, provided the original author and source are credited. 